\title{
EFFECT OF TEMPERATURE DEGREES ON SOME BIOLOGICAL ASPECTS OF HELICOVERPA ARMIGERA IN RELATION TO BIOCHEMICAL CONTENTS
}

\author{
A. A. A. Zaki \\ Plant Protection Research Institute, Agricultural Research Center, Dokki, Giza Egypt
}

Received: Sep. 11, 2017

Accepted: Oct. 3, 2017

\begin{abstract}
The temperature effect on some biological aspects and biochemical of Helicoverpa armigera reared on bell pepper were conducted under laboratory conditions in Plant Protection Research Institute Sharkia branch, ARC to study the effect of three temperatures $\left(21,24\right.$ and $27 \pm 1^{\circ} \mathrm{C}$ ). The results showed that the incubation period of $\mathrm{H}$. armigera eggs were $4.10,3.70$ and 2.50 days at 21,24 and $27^{\circ} \mathrm{C}$, respectively. Larval and pupal duration were decreased as temperature increased. Generation period lasted 52.50, 42.01 and 31.67 days, respectively. The thresholds of development ( $\left.T_{0}\right)$ were 12.30, 11.50, 11.85, 11.90 and $12.50{ }^{\circ} \mathrm{C}$ for eggs, larvae, pupae, pre- oviposition and generation period, respectively. While, the average of thermal units required to complete the developmental stages were 38.57, 275.44, 149.93, 32.58 and 462.86 unit, respectively, when reared on bell pepper. The total eggs laid by female high significantly affected by all temperatures. Decreased at temperature from 24 to $21^{\circ} \mathrm{C}$ caused decreased in total lipid, protein and carbohydrate but the increase from 24 to $27^{\circ} \mathrm{C}$ caused decreased in all parameters except carbohydrate caused increased.
\end{abstract}

Key words: Cotton bollworm, temperature, Capsicum annuum, life cycle, biochemical

\section{INTRODUCTION}

The cotton bollworm, Helicoverpa armigera (Hüb.) (Lepidoptera: Noctuidae), is an extremely polyphagous species and a common insect pest of many crops in Egypt Nada et al., (2004) and many parts of the world Reddy et al., (2004). The larvae of this $H$. armigera also attack tomato, corn, tobacco, chick pea, pepper, okra, carnation, and gladiolus in Greece Pelekassis (1962). $H$. armigera was reared on six host plants: cotton, corn, tomato, hot pepper, tobacco and common bean. They found that the larvae were successfully survived on all six host plants, although mortality was very high. The developmental time of immature stages reared on hot pepper and tomato were 32.91 and 27.96 days, respectively Zhudong Liu et al., (2004). The effect of temperature were studied on the rate of development for $H$. armigera reared on tomato. The duration of different life history stages decreased as temperature increased from 13.3 to $32.5{ }^{\circ} \mathrm{C}$. A development threshold of $10.5,11.3$ and $13.8{ }^{\circ} \mathrm{C}$ was estimated for the eggs, larvae and pupal stages, respectively Jallow and Matsura (2001). The lowest developmental thresholds of the immature stages of Helicoverpa armigera was reared on an artificial diet and it were estimated by a linear model and ranged from 10.17 (pupal stage) to $11.95{ }^{\circ} \mathrm{C}$ (egg stage) at constant temperature regimes. Mean adult longevity fluctuated from $34.4 \mathrm{~d}$ at $15{ }^{\circ} \mathrm{C}$ to $7.6 \mathrm{~d}$ ate $35{ }^{\circ} \mathrm{C}$ Mironidis and Savopoulou (2008). Stated that the temperature increasing led to an increase in the developmental rate and reduces the development periods of the different stages. The generation period of $H$. armigera reared on lettuce was shorter (32.23 days) than that reared on pea (34.70 days). The lower developmental temperatures were 11.60 and $11.39{ }^{\circ} \mathrm{C}$ for the generation and the thermal units required were 467.13 and 511.26 DD's, respectively Amer and El-sayed (2015). The thermal requirements (degree-days) of 
development was often used for estimating developmental times because temperature has a major effect in determining the rate which $H$. armigera develop Zaslavski, (1988). Developmental processes are controlled by temperature dependent on biochemical reactions, which are restricted by lower and upper thresholds Domos and Soultani, (2008). Tested temperatures 16 and $37^{\circ} \mathrm{C}$ caused high reduction in soluble protein and total lipid in larvae compared to the larvae reared at $26^{\circ} \mathrm{C}$., Glucose activity greatly reduced in $E$. insulana larvae reared on okra at 16,32 and $37^{\circ} \mathrm{C}$. Kandil Mervat (2013).

The objectives of the current study were to investigate the effect of constant temperatures and fed on bell pepper, Capsicum annuum on some biological aspects and biochemical of $H$. armigera in order to determine the lower threshold temperature.

\section{MATERIALS AND METHODS 1- Host plant:}

The host plant used in this study was: bell pepper, Capsicum annum

\section{2- Insect rearing:}

The American bollworm, $H$. armigera, (ABW) larvae were collected from bell pepper fields of Zagazig district and placed individual in glass tubes in November 2016 and incubated under laboratory at a temperature of $27 \pm 1^{\circ} \mathrm{C}$ and $70 \pm 5 \% \mathrm{RH}$ and light period 14 light :10 dark. The larvae were feed daily on bell pepper fruits washed with water until pupation. Pupae were transferred to clean glass tubes and incubated until moth emergence. When adults emerged, moths were sexed and (five pairs) in each cage and it left till egg laying. Moths were provided with $10 \%$ sugar solution on a cotton swab. The laid eggs were separated daily and placed in glass jars. The eggs incubated on the previous laboratory conditions until hatching.

\section{3- Effect of temperature and host plant on the American bollworm:}

The newly hatched larvae were transferred individually to glass tubes (3.5 $\mathrm{x}$ $7 \mathrm{~cm}$ ) containing bell pepper and changed daily with fresh one until pupation. 450 glass tubs were prepared as three treatments: 21, 24 and $27{ }^{\circ} \mathrm{C}$. Each treatment was divided into three replicates 50 larvae in each replicate. Tubes were examined daily until larval pupation to record larval duration and larval mortality percentages. Pupae were transferred to clean glass tubs and examined until moth emergence to record pupal duration, pupal mortality and pupal weight. When adults emerged, moths were sexed and caged to egg laying. Five replicates of two pairs/each treatment. Moths were provided with $10 \%$ sugar solution. The cages was inspected daily until moth death. The pre-oviposition, oviposition and post- oviposition periods and longevity of adult females and males were calculated. Eggs laid on the same day in each temperature was placed in glass jar and incubated under the same temperatures. Three replicates of 100 eggs/each treatment. Incubation periods were calculated.

\section{4-Statistical analysis:}

The effect of host plant, and temperatures degrees on developmental time of $\mathrm{H}$. armigera was determined by one way analysis of variance (ANOVA) and Duncan's multiple range tests of means were used (Duncan's, (1957). The relationship between temperature and mean developmental rate of each stage and generation under tested temperature was determined using liner regression. For tested temperature degree in each treatment, developmental rate (DR) was calculated as reciprocals of development time (D) for each stage (DR= 1/D). The relation between developmental rate and temperature $(T)$ was determined using liner regression equation: $\mathrm{DR}=\mathrm{a}+\mathrm{bT}$, whereas: $a$ and $b$ parameters of the liner regression. 
The lower developmental threshold (t0) was determined: $t_{0}=-a / b$. Thermal units (degree days $\left.=D^{2},{ }^{s}\right)$ required for complete development of larvae were calculated according to Arnold (1959). DD $s=\mathrm{d}^{*}\left(\mathrm{~T}-\mathrm{t}_{0}\right)$ whereas $d=$ duration, $T=$ temperature and $t_{0}$ $=$ lower developmental temperature.

\section{5- Biochemical analysis:}

To study the effect of temperature on some biochemical parameters. The samples of ABW larvae were collected after 14 days at 21,24 and $27^{\circ} \mathrm{C}$ and kept in clean tubes in a refrigerator at $4{ }^{\circ} \mathrm{C}$ for chemical analysis. Total protein, lipids and carbohydrate were determined colorimetrically according to Koller (1984).

\section{RESULTS AND DISCUSSION Duration of different stages:}

Data in Table (1) showed the durations of ABW different stages reared on bell pepper at three constant temperatures 21,24 and $27^{\circ} \mathrm{C}$ was decreased as temperature increased. The incubation periods of $A B W$ reared on Bell pepper were 4.10, 3.70 and 2.50 days at 21,24 and $27^{\circ} \mathrm{C}$, respectively. The average of incubation periods was 3.43 days.

The larval durations were $28.00,23.66$ and 17.07 days when the larvae reared on bell pepper at 21,24 and $27^{\circ} \mathrm{C}$, respectively. The average of larval duration was 22.91 days. The pupal duration of the ABW were $17.00,11.75$ and 10.00 days, respectively. The average of pupal duration was 12.91 days. The pre-oviposition periods were 3.40 , 2.90 and 2.10 days, respectively whereas the average was 2.80 days. The oviposition periods were $11.10,10.00$ and 7.33 days, respectively. The post-oviposition periods were $4.10,3.00$ and 2.00 days, respectively. The adult females longevity were 18.60 , 15.90 and 11.43 days, respectively. Regarding generation period, (egg to egg), data indicated that $A B W$, generation on Bell pepper were $52.50,42.01$ and 31.67 days at 21,24 and $27^{\circ} \mathrm{C}$., respectively whereas the average was 42.06 days. Jallow and Matsura (2001) studied that the effect of temperature was studied on the rate of development for $H$. armigera reared on tomato. The duration of different life history stages decreased as temperature increased from 13.3 to $32.5{ }^{\circ} \mathrm{C}$. A development threshold of 10.5, 11.3 and $13.8{ }^{\circ} \mathrm{C}$ was estimated for the eggs, larvae and pupal stages, respectively. Zhudong Liu et al., (2004) they stated that $H$. armigera was reared on six host plants: cotton, corn, tomato, hot pepper, tobacco and common bean. They found that the larvae were successfully survived on all six host plants, although mortality was very high on hot pepper and tomato. The developmental time of immature stages reared on hot pepper and tomato were 32.91 and 27.96 days, respectively. Al-Shannaf and El-Sayed (2010) found that increasing the temperature from 20 to $30{ }^{\circ} \mathrm{C}$ caused decreased in the duration of the different stages of Spodoptera littoralis. Larval and pupal developmental periods were influenced by the host plants. Zero developmental temperature ( $\left.\mathrm{t}_{0}\right)$ differed according to the host plant fed.

\section{Rate of development:}

Data in Table (2) showed that the average of developmental rate for the ABW different stages increased as temperature increased it were $0.29,0.04,0.07,0.35$ and 0.02 for eggs, larvae, pupae, pre oviposition period and generation at 21,24 and $27^{\circ} \mathrm{C}$., respectively. Amer and El-sayed (2015) they found that temperatures $\left(23,27\right.$ and $30^{\circ} \mathrm{C}$ ) tested were increased led to an increase in the developmental rate and reduces the development periods of the different stages of ABW. The generation period of $H$. armigera reared on lettuce was shorter (32.23 days) than that reared on pea (34.70 days). The lower developmental temperatures were 11.60 and $11.39{ }^{\circ} \mathrm{C}$ for the generation and the thermal units required were 467.13 and 511.26 DD's, respectively when feed on lettuce. 
Table (1): Duration of different stages of the $H$. armigera reared on Capsicum annuum at constant temperatures

\begin{tabular}{|c|c|c|c|c|}
\hline \multirow{2}{*}{ Stages } & \multicolumn{4}{|c|}{ Temperature degrees } \\
\hline & $21^{\circ} \mathrm{C}$ & $24^{\circ} \mathrm{C}$ & $27^{\circ} \mathrm{C}$ & Average \\
\hline Egg & 4.10 & 3.70 & 2.50 & 3.43 \\
\hline Larva & 28.00 & 23.66 & 17.07 & 22.91 \\
\hline Pupa & 17.00 & 11.75 & 10.00 & 12.91 \\
\hline Pre-oviposition period & 3.40 & 2.90 & 2.10 & 2.80 \\
\hline $\begin{array}{l}\text { Ovi- oviposition } \\
\text { period }\end{array}$ & 11.10 & 10.00 & 7.33 & 9.47 \\
\hline $\begin{array}{l}\text { Post oviposition } \\
\text { period }\end{array}$ & 4.10 & 3.00 & 2.00 & 3.03 \\
\hline Adult & 18.60 & 15.90 & 11.43 & 15.31 \\
\hline Generation & 52.50 & 42.01 & 31.67 & 42.06 \\
\hline
\end{tabular}

Table (2): Development rate of different stages of the $H$. armigera reared on bell pepper, C. annuum at constant temperatures

\begin{tabular}{|c|c|c|c|c|}
\hline \multirow{2}{*}{ Stage } & \multicolumn{4}{|c|}{ Temperature degrees ${ }^{\circ} \mathrm{C}$} \\
\cline { 2 - 5 } & $21^{\circ} \mathrm{C}$ & $24^{\circ} \mathrm{C}$ & $27^{\circ} \mathrm{C}$ & Average \\
\hline Egg & 0.24 & 0.27 & 0.40 & 0.29 \\
\hline Larva & 0.03 & 0.04 & 0.05 & 0.04 \\
\hline Pupa & 0.05 & 0.08 & 0.10 & 0.07 \\
\hline Pre-oviposition period & 0.29 & 0.34 & 0.47 & 0.35 \\
\hline Generation & 0.01 & 0.02 & 0.03 & 0.02 \\
\hline
\end{tabular}

\section{Lower developmental threshold:}

The lower developmental threshold for ABW different stages reared on Bell pepper were $12.30,11.50,11.85,11.90$ and $12.50^{\circ} \mathrm{C}$ for egg, larvae, pupae, pre oviposition and generation, respectively Table (3). 
Table (3): Lower threshold temperature for different stages of the $H$. armigera reared on C. annuum

\begin{tabular}{|c|c|c|c|}
\hline \multirow{2}{*}{ Stage } & \multicolumn{2}{|c|}{ Regression equation } & \multirow{2}{*}{$\begin{array}{l}\text { Lower threshold temperature } \\
\qquad\left({ }^{\circ} \mathrm{C}\right)\end{array}$} \\
\hline & a & $b$ & \\
\hline Egg & -0.32 & 0.026 & 12.30 \\
\hline Larva & -0.046 & 0.004 & 11.50 \\
\hline Pupa & -0.083 & 0.007 & 11.85 \\
\hline Pre-oviposition period & -0.357 & 0.03 & 11.90 \\
\hline Generation & -0.025 & 0.002 & 12.50 \\
\hline
\end{tabular}

Mironidis and Savopoulou (2008) stated that the lowest developmental thresholds of the immature stages of $H$. armigera was reared on an artificial diet and it were estimated by a linear model and ranged from 10.17 (pupal stage) to $11.95{ }^{\circ} \mathrm{C}$ (egg stage) at constant temperature regimes. Mean adult longevity fluctuated from 34.4 day at $15^{\circ} \mathrm{C}$ to 7.6 day ate $35^{\circ} \mathrm{C}$.

\section{Thermal units requirement:}

The average thermal units (degree-days) required for egg development till hatched was 38.57 DD's. The average of the thermal units required for larval complete development was 275.45 DD's. The average of the thermal units required for pupal development until moths emergence was 149.94 DD's. While, for pre-oviposition period the average of the thermal units required was 32.58 DD's. The average of thermal units required to complete generation period was 462.86 DD's Table (4). Zaslavski, (1988) found that the thermal requirements of development were often used for estimating developmental times because temperature has a major effect in determining the rate which $H$. armigera develop.

\section{Biological aspects of American bollworm reared on bell pepper at constant temperature:}

\section{Larval stage:}

The mean larval weights were decreased significantly as temperature increased. The average mortality percentage of larval stage was 38.98 days.

\section{Pupal stage:}

Data given Table (5) showed that the pupal weights were decreased significantly as temperature increased when female fed on Bell pepper. The pupation percentages were $46.00,66.00$, and $77.00 \%$. The pupal mortality was increased significant as 18.12 $\%$. Increase the temperature from 21 to 27 degrees caused shorten the duration of the larvae, pupae, weight and pupation percentage while larval mortality percentage was decreased.

\section{Adult emergence percentage:}

Data given in Table (6) showed that temperature was effect significantly on adult emergence percentage were $75.00,81.74$ and $88.89 \%$, respectively.

\section{Adult female longevity:}

The pre-oviposition and oviposition periods were significantly increased as temperature increased while the average of post-oviposition was 3.03 day. The female and male longevity of the ABW moths was high significantly effect under different 
temperatures and it were 15.31 and 13.05 days, respectively.

\section{Eggs laying:}

Data given in Table (6) showed that the average number of eggs deposited per female were high significant affect with temperature.

\section{Hatchability percentage:}

The hatchability percentages of ABW eggs were $76.00,80.00$ and $83.00 \%$ at 21 , 24 and $27^{\circ} \mathrm{C}$, receptively (Table, 6). The hatchability percentages were increased as temperature increased. Greenberg et al.,
(2001) found that development times and life table parameters of Spodoptera exigua, were determined on five host plants: cabbage, Brassica oleracea capitata; cotton, Gossypium hirsutum; bell pepper, Capsicum annuum; pigweed, Amaranthus retroflexus; and sunfower, Helianthus annuus. Significant relationships were found between pupal weight and subsequent adult fecundity on all host plants. Duration of the larval stage was shortest on pigweed (12.4 d) and longest on pepper (18.0 d). Larval survival was highest on pigweed (94.4\%) and lowest on cabbage (67.1\%).

Table (4): Thermal unit for different stages of the $H$. armigera reared on $C$. annuum

\begin{tabular}{|c|c|c|c|c|}
\hline \multirow{2}{*}{ Stage } & \multicolumn{4}{|c|}{ Temperature degrees ${ }^{\circ} \mathrm{C}$} \\
\cline { 2 - 5 } & $21^{\circ} \mathrm{C}$ & $24^{\circ} \mathrm{C}$ & $27^{\circ} \mathrm{C}$ & Average \\
\hline Egg & 35.67 & 43.29 & 36.75 & 38.57 \\
\hline Larva & 266.00 & 295.75 & 264.59 & 275.44 \\
\hline Pupa & 155.55 & 142.76 & 151.50 & 149.93 \\
\hline Pre-oviposition period & 30.94 & 35.09 & 31.71 & 32.58 \\
\hline Generation & 446.25 & 483.11 & 459.21 & 462.86 \\
\hline
\end{tabular}

Table (5): Biological aspects of immature stages of $H$. armigera reared on $C$. annuum

\begin{tabular}{|c|c|c|c|c|c|c|c|}
\hline \multirow{2}{*}{ Temperatures } & \multicolumn{3}{|c|}{ Larval stage } & \multicolumn{4}{c|}{ Pupal stage } \\
\cline { 2 - 8 } & $\begin{array}{c}\text { duration } \\
\text { days }\end{array}$ & $\begin{array}{c}\text { weight } \\
\mathrm{g}\end{array}$ & $\begin{array}{c}\text { Mortality } \\
\%\end{array}$ & $\begin{array}{c}\text { duration } \\
\text { days }\end{array}$ & $\begin{array}{c}\text { weight } \\
\mathrm{g}\end{array}$ & $\begin{array}{c}\text { Pupation } \\
\%\end{array}$ & $\begin{array}{c}\text { Mortality } \\
\%\end{array}$ \\
\hline $21^{\circ} \mathrm{C}$ & $28.00 \mathrm{a}$ & $0.31 \mathrm{a}$ & $54.00 \mathrm{a}$ & $17.00 \mathrm{a}$ & 0.28 & $46.00 \mathrm{c}$ & $25.00 \mathrm{a}$ \\
\hline $24^{\circ} \mathrm{C}$ & $23.66 \mathrm{~b}$ & $0.30 \mathrm{a}$ & $34.00 \mathrm{~b}$ & $11.75 \mathrm{~b}$ & 0.25 & $66.00 \mathrm{~b}$ & $18.26 \mathrm{~b}$ \\
\hline $27^{\circ} \mathrm{C}$ & $17.07 \mathrm{c}$ & $0.26 \mathrm{~b}$ & $28.94 \mathrm{~b}$ & $10.00 \mathrm{~b}$ & 0.23 & $71.06 \mathrm{a}$ & $11.11 \mathrm{c}$ \\
\hline Average & 22.91 & 0.29 & 38.98 & 12.91 & 0.25 & 61.02 & 18.12 \\
\hline $\mathrm{P}$ & $0.0008^{\star *}$ & $0.0104^{*}$ & $0.0001^{* *}$ & $0.0015^{\star *}$ & Ns & $0.0001^{* *}$ & $0.0032^{\star *}$ \\
\hline LSD 0.05 & 3.48 & 0.03 & 5.88 & 2.61 & - & 6.24 & 5.78 \\
\hline
\end{tabular}


Effect of temperature degrees on some biological aspects of ....................

Table (6): Adult longevity and reproductive potential of $H$. armigera reared on $C$. annuum

\begin{tabular}{|c|c|c|c|c|c|c|c|c|}
\hline \multirow{2}{*}{$\begin{array}{c}\text { Temperatures } \\
{ }^{\circ} \mathrm{C}\end{array}$} & \multirow{2}{*}{$\begin{array}{c}\text { Adult } \\
\text { emergency\% }\end{array}$} & \multicolumn{3}{|c|}{ Ovipositional period/ days } & \multicolumn{2}{|c|}{ Longevity (days) } & \multirow{2}{*}{$\begin{array}{c}\text { No. of } \\
\text { eggs/female }\end{array}$} & \multirow{2}{*}{$\begin{array}{c}\text { Hatchability } \\
\%\end{array}$} \\
\hline & & $\mid \begin{array}{c}\text { Pre- } \\
\text { oviposition }\end{array}$ & Oviposition & $\begin{array}{c}\text { Post- } \\
\text { oviposition }\end{array}$ & n Female & Male & & \\
\hline $21^{\circ} \mathrm{C}$ & $75.00 \mathrm{c}$ & $3.40 a$ & $11.10 \mathrm{a}$ & $4.10 a$ & $18.60 a$ & $15.90 \mathrm{a}$ & $250.0 c$ & 76.00 \\
\hline $24^{\circ} \mathrm{C}$ & $81.74 b$ & $2.90 \mathrm{~b}$ & $10.00 \mathrm{a}$ & $3.00 \mathrm{~b}$ & $15.90 a$ & $12.75 b$ & $371.0 \mathrm{a}$ & 80.00 \\
\hline $27^{\circ} \mathrm{C}$ & $88.89 a$ & $2.10 \mathrm{c}$ & $7.33 b$ & $2.00 \mathrm{c}$ & $11.43 b$ & $10.50 \mathrm{~b}$ & $297.0 \mathrm{~b}$ & 83.00 \\
\hline Average & 81.87 & 2.80 & 9.47 & 3.03 & 15.31 & 13.05 & 306.0 & 79.66 \\
\hline $\mathrm{P}$ & $0.0002^{* *}$ & $0.0003^{\star *}$ & $0.0131^{*}$ & $0.000^{\star *}$ & $0.0032^{*}$ & $\star 0.0078^{\star \star}$ & $0.0001^{\star \star}$ & ns \\
\hline LSD 0.05 & 3.46 & 0.35 & 2.15 & 0.13 & 3.01 & 2.69 & 28.02 & - \\
\hline
\end{tabular}

NS : Non-significant $\quad$ *:Significant $\quad$ **:Highly significant

\section{Biochemical analysis: Total soluble protein:}

The total soluble protein were 8.78 , 37.43 and $29.98 \mathrm{mg} / \mathrm{ml}$, respectively. From these data can be concluded that the high level of total soluble protein 37.43 at $24^{\circ} \mathrm{C}$ while the lowest values was 8.78 at $21^{\circ} \mathrm{C}$ Table (7).

\section{Total lipid:}

Data in Table (7) indicated that the total lipid contents were 229. 68, 280.82 and $173.96 \mathrm{mg} / \mathrm{ml}$, when larvae reared at 21, 24 and $27{ }^{\circ} \mathrm{C}$, respectively. From these data can be concluded that the high level of total lipid $280.82 \mathrm{mg} / \mathrm{ml}$ at $24{ }^{\circ} \mathrm{C}$ while the lowest values was $173.96 \mathrm{mg} / \mathrm{ml}$ at $27^{\circ} \mathrm{C}$.

\section{Total carbohydrates:}

Data in Table (7) show that the total carbohydrates in $H$. armigera larvae reared on Bell pepper at 21,24 and $27{ }^{\circ} \mathrm{C}$ were $15.61,23.71$ and $28.41 \mathrm{mg} / \mathrm{ml}$. From these data can be concluded that the high level of total carbohydrates 28.41 at $27^{\circ} \mathrm{C}$ while the lowest values was $15.61 \mathrm{mg} / \mathrm{ml}$ at $21^{\circ} \mathrm{C}$.

Keeley (1985) recorded that in insect adult females, the major function of the fat body is the synthesis and release of vitellogenic proteins and lipids for yolk formation during oocyte maturation. Also, decreased the total lipid caused decreased on the mean number of eggs and hatchability percentage for Spodoptera exigua adult. Kandil Mervat (2013) tested temperatures $16,21,32$ and $37^{\circ} \mathrm{C}$ caused high reduction in total soluble protein in larvae compared to the larvae reared at 26 ${ }^{\circ} \mathrm{C}$. indicated that the high reduction in total lipid contents were 2.15, 4.89, 2.88 and $1.69 \mathrm{mg} / \mathrm{ml}$, when larvae reared at 16, 21, 32 and $37{ }^{\circ} \mathrm{C}$, respectively, compared with $26^{\circ} \mathrm{C}$, which recorded the high level of total lipid (8.07 glucose activity greatly reduced in $E$. insulana larvae reared on okra at 16 , 32 and $37^{\circ} \mathrm{C}$.

In conclusion, the decreased as temperature from 24 to $21{ }^{\circ} \mathrm{C}$ caused decreased in total lipid, total protein and total carbohydrate but 24 to $27^{\circ} \mathrm{C}$ caused decreased except carbohydrate caused increased. The reduction in total lipid, total protein and total carbohydrate caused reduction in the number of deposited eggs of $H$. armigera adult female. 
Table (7): Effect of temperatures on some biochemical analyzed of $\boldsymbol{H}$. armigera

\begin{tabular}{|c|c|c|c|}
\hline $\begin{array}{c}\text { Temperatures } \\
{ }^{\circ} \mathrm{C}\end{array}$ & Total Protein $\mathrm{mg} / \mathrm{ml}$ & $\begin{array}{c}\text { Total Lipid } \\
\mathrm{mg} / \mathrm{ml}\end{array}$ & $\begin{array}{c}\text { Total Carbohydrate } \\
\mathrm{mg} / \mathrm{ml}\end{array}$ \\
\hline $21^{\circ} \mathrm{C}$ & 8.78 & 229.68 & 15.61 \\
\hline $24^{\circ} \mathrm{C}$ & 37.43 & 280.82 & 23.71 \\
\hline $27^{\circ} \mathrm{C}$ & 29.98 & 173.96 & 28.41 \\
\hline
\end{tabular}

\section{REFERENCES}

Al-Shannaf and A. A. A. El-Sayed (2010). Effect of host plants on the required heat units of Spodoptera littoralis (Boisd.) (Lepidoptera: Noctuidae). Bull. Ent. Soc. Egypt, (87):79-88.

Arnold, C. Y. (1959). The determination and significant of the base temperature in a linear heat unite system . Proc. American Soc. Hort. Sci., 74 : 430-445.

Amer, A. E. A. and A. A. A. EL-Sayed (2015). Lower threshold temperature and thermal unit of American bollworm, Helicoverpa armigera (Hübner) reared on pea and lettuce and its rearing on a new modified artificial diets. J. Product \& Dev. 20 (3): 273-284.

Domos, P. T. and M. S. Soultani (2008). Temperature dependent bionomics and modeling of Anarsia lineatella (Lepidoptera: Gelechiidae) in the laboratory. Entomol. Soci. of America, 101:1557-1567.

Duncan, D. (1957). Multiple range tests for correlated and hetroscedastic means. Biometric, 13:164-176.

Greenberg, S. M., T. W. Sappington, B. C. Legaspi, JR. T.-X. Liu and M. SE ' Tamou (2001). Feeding and life history of Spodoptera exigua (Lepidoptera: Noctuidae) on different host plants. Ann. Entomol. Soci. Am., 94(4): 566-575

Jallow, M. F. A. and M. Matsura (2001). Influence of temperature on the rate of development of Helicoverpa armigera (HÜbner) (Lepidoptera: Noctuidae). Appl. Entomol. Zool. 36 (4):427-430.

Mironidis, G. K. and M. Savopoulou-Soultani (2008). Development, Survivorship, and reproduction of Helicoverpa armigera (Lepidoptera: Noctuidae) under constant and alternating temperatures. Environ. Entomol. 37 (1): 16-28.
Nada, M. A., M. G. Ragab and E. S. Mansour (2004). Seasonal abundance and prediction possibility of American bollworm, Helicoverpa armigera (Hub.) in relation to pheromone trap catches and heat unit accumulated. Egypt. J. Appl. Sci., 19 (11): 294-409.

Kandil, Mervat A. A. (2013). Relationship between temperature and some biological aspects and biochemical of Earias insulana (Boisd.) (Lepidoptera: Noctuidae). Egypt. Acad. J. Biol. Sci., 6(1): 11-20.

Keeley, L. L. (1985). Physiology and biochemistry of fat body. In Comprehensive Insect Biochemistry, Physiology and Pharmacology (Edited by Kerkut G.A and Gilbert, L.L.) vol. 3, pp. 211-248. Pergamon Press, Oxford.

Koller, A. (1984). Total serum protein. Kaplan A. et al. Clin. Chem. The C.V. Mosby Co. St. Louis. Toronto. Princeton. 1316-1324.

Reddy, K. S.; G. R. Rao; P. A. Rao and P. Rajasekhar (2004): Life table studies of the capitulum borer, Helicoverpa armigera (Hübner) infesting sunflower. J. Entomol. Res., 28: 13-18.

Pelekassis, C. E. D. (1962): A catalogue of the more important insects and other animals harmful to the agricultural crops of Greece during the last thirty year period. Ann. Inst. Phytopath. Benaki N. S. 5: 5-104.

Zaslavski, V. A. (1988): Insect development: photoperiodic and temperature control. Springer- Verlag, Berlin, N.Y. :187 pp.

Zhudong Liu , Dianmo Li , Peiyu Gong , and Kunjun Wu. (2004): Life table studies of the cotton bollworm, Helicoverpa armigera (Hübner) (Lepidoptera: Noctuidae), on different host plants. Environ. Entomol., 33 (6):1570-1576. 


\title{
تأثير درجات الحرارة على بعض الخصائص البيولوجية لاودة اللوز الأمريكية في علاقة

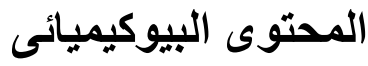

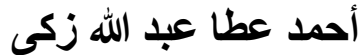

معهد بحوث وقاية النباتاتـ مركز البحوث الزر اعية ـالدقي -جيزة ـمصر

أجريت هذه التجربه تحت الظروف الترف المعملية فى معهد بحوث وقاية النباتات ـ قسم بحوث ديدان اللوز بهدف در اسة تأثير

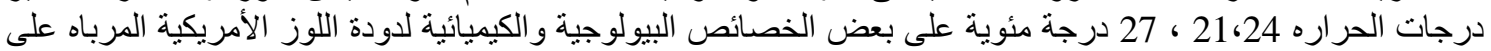

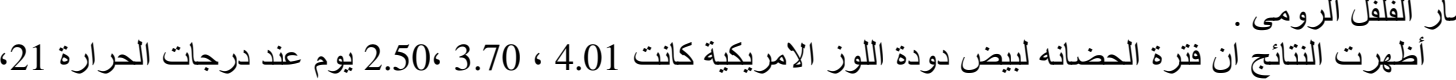

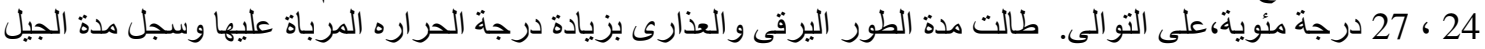

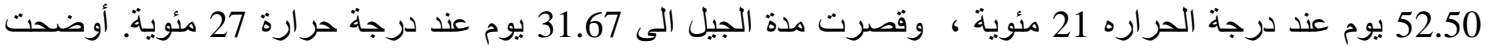

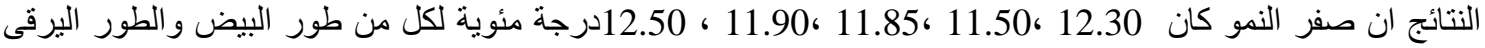
و العذارى وفتره ماقبل وضع البيض و ومدة الجيل ، على التو الى. كان متوسط الوحدات الحراريه 3250

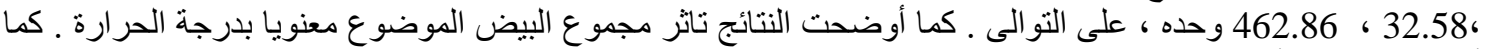

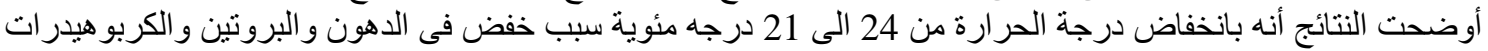

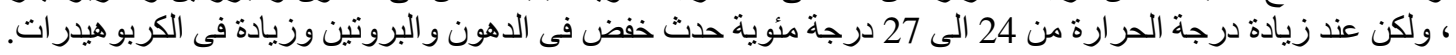

